\title{
Polymerase Chain Reaction detection of deformed wing virus (DWV) in Apis mellifera and Varroa destructor
}

\author{
Diana TENTCHEVA ${ }^{\mathrm{a}}$, Laurent GAUTHIER ${ }^{\mathrm{a} *}$, Sandrine JOUVE $^{\mathrm{a}}$, \\ Laetitia CANABADY-RoCHELlE ${ }^{\mathrm{a}}$, Benjamin DAINAT ${ }^{\mathrm{a}}$, François CousserAns ${ }^{\mathrm{a}}$, \\ Marc Edouard COLIN ${ }^{\mathrm{a}}$, Brenda V. BALL ${ }^{\mathrm{b}}$, Max BERGOIN ${ }^{\mathrm{a}}$ \\ a Laboratoire de Pathologie Comparée des Invertébrés UMR5087, Université Montpellier II, 34095 Montpellier, \\ France \\ b Plant \& Invertebrate Ecology Division, Rothamsted Research, Harpenden, Herts, AL5 2JQ, UK
}

(Received 29 July 2003; revised 6 November 2003; accepted 8 December 2003)

\begin{abstract}
We have developed a specific assay for the detection of deformed wing virus (DWV) in Apis mellifera L. and Varroa destructor based on the reverse transcriptase polymerase chain reaction (RT-PCR) technology. Primers were designed from the sequence of a 4700 nucleotides cDNA fragment located in the 3'-end of the DWV genome. This fragment encodes a single open reading frame of 1565 amino acids showing similarity to viral RNA dependent RNA polymerase consensus motif. RT-PCR assays from DWV infected individual mite or bee produced a 395 nucleotide DNA fragment clearly identifiable by agarose gel electrophoresis. The signal in bees having deformed wings was significantly higher than in normal ones. A search for DWV in 40 colonies showed that DWV is broadly distributed in bee colonies and mites. As an average, greater virus prevalence of virus was detected in bees collected in autumn compared to bees collected in spring or during the summer period.
\end{abstract}

deformed wing virus (DWV) / diagnosis / bee virus / Varroa destructor

\section{INTRODUCTION}

The impact of viral diseases on honey bee populations and their role in colony mortality commonly observed in apiaries severely infested with Varroa destructor (Anderson and Trueman, 2000) are still controversial. The great diversity of viruses isolated from bees, the lack of specific symptoms and the limited availability of tools for rapid and largescale diagnosis are partly responsible for this situation. The complete or partial sequencing of several picorna-like viruses of the honey bee has allowed the recent development of new more sensitive methods of detection based on amplification by reverse transcription polymerase chain reaction of specific virus sequences. Originally developed for the diagnosis of human and animal RNA viruses, these methods have been successfully adapted to identify several RNA bee viruses including sacbrood virus (SBV), Kashmir bee virus (KBV), chronic bee paralysis virus (CBPV), acute bee paralysis virus (ABPV) and black queen cell virus (BQCV) (Grabensteiner et al., 2001; Stoltz et al., 1995; Ribière et al., 2002; Benjeddou et al., 2001).

Deformed wing virus (DWV) is another small RNA virus which is thought to be associated with symptoms of wing deformity during pupation of Apis mellifera L. in bee colonies severely infested by $V$. destructor (Ball, 1989; Bailey and Ball, 1991). This virus was previously detected by ELISA tests both in adult bees and in mites, and bees exhibiting symptoms of wing deformity were shown to

\footnotetext{
* Corresponding author: gauthier@ crit.univ-montp2.fr
} 
carry larger amounts of DWV than asymptomatic ones (Bowen-Walker et al., 1999). However, the mechanism that leads to wing deformity following DWV infection is still unclear.

In an attempt to elucidate the relationship between honey bees, DWV and V. destructor, we have developed a RT-PCR assay to identify this virus in honey bee colonies and in mites after the partial sequencing of the DWV genome. Using a set of DWV specific primers, we have looked for DWV in bee and mite populations in 4 apiaries located in different regions in France.

Our results show that DWV is broadly distributed both in bee colonies and in $V$. destructor populations, with a much greater prevalence during autumn.

\section{MATERIALS AND METHODS}

\subsection{Sampling of bees and mites}

Four apiaries in different regions of France were included in this study. The localisation of each apiary in France is indicated in Table I.

In each apiary, adult bees, brood and $V$. destructor mites, were harvested by beekeepers at three periods of the 2002 year (April, July and September), from 10 different colonies. The samples were immediately sent by mail to the laboratory and frozen at $-20^{\circ} \mathrm{C}$ (the bee pupae were carefully removed from capped cells with a toothpick before freezing). Mites were collected after treatment with acaricide (amitraze) at the end of August, except in the Ouessant island apiary.

For large scale survey, pooled samples of 100 adult bees, 30 bee pupae, or 100 mites were used. Bee samples were carefully checked to avoid the inclusion of contaminating mites.

Experimentally infected bees, used as control for examining the presence of different bee viruses in the samples by PCR or by ELISA, were kindly provided by Dr. Ball (Rothamsted, UK).

\subsection{Partial cloning of DWV genome}

Three gram of mites (approximately 10000 mites) were collected after amitraze treatment in an apiary located near Pau (South West of France). The mites were homogenized in $100 \mathrm{ml}$ extraction buffer (10 mM Tris pH 7.2;0.4 M NaCl). This mite homogenate was checked for the absence of other bee viruses by ELISA (for slow paralysis virus, cloudy wing virus, ABPV) or by RT-PCR (for $\mathrm{KBV}, \mathrm{ABPV}, \mathrm{BQCV}, \mathrm{SBV}, \mathrm{CBPV})$, using published protocols (Allen et al., 1986, Stoltz et al., 1995; Benjeddou et al., 2001; Grabensteiner et al., 2001; Ribière et al., 2002). The homogenate was clarified by centrifugation at $4000 \mathrm{~g}$ and the volume was reduced to $15 \mathrm{~mL}$ on an Amicon concentrator $8400^{\circledR}$ (Millipore). The homogenate was then loaded onto a $20 \%-60 \%$ sucrose gradient and centrifuged at $25000 \mathrm{rpm}$ for 3 hours in a Beckman 7L 55 ultracentrifuge using the SW28 rotor. Fractions were collected and analysed by negative staining electron microscopy using a standard protocol. Fractions containing virus were pooled and concentrated on Ultrafree ${ }^{\circledR} 15$ (Millipore) to $250 \mu \mathrm{L}$ final volume. One milliliter of Trizol ${ }^{\circledR}$ (Invitrogen) plus $300 \mu \mathrm{g}$ of glycogen were added and total RNA was extracted following supplier recommendation. Five hundred nanogram of total RNA was reverse-transcribed with Superscript-II ${ }^{\circledR}$ reverse transcriptase (Invitrogen) at $25^{\circ} \mathrm{C}$ for $10 \mathrm{~min}$ and for 1 hour at $42{ }^{\circ} \mathrm{C}$. The reaction mixture was as follows: $0.5 \mu \mathrm{g}$ total RNA, 25 pmol oligo d(T) $)_{20}$ primer, $500 \mu \mathrm{M}$ dNTPs, Superscript-II ${ }^{\circledR}$ buffer, 10 mM DTT, 2 units Superscript-II ${ }^{\circledR}$. Reverse transcriptase was inactivated at $70{ }^{\circ} \mathrm{C}$ for $15 \mathrm{~min}$ and 1 unit Rnase $\mathrm{H}$ (Roche) was added to the reaction mix and incubated at $37{ }^{\circ} \mathrm{C}$ for $20 \mathrm{~min}$. Synthesis of the second strand was performed as follows: $15 \mu \mathrm{L}$ of first strand reaction were mixed with $10 \mu \mathrm{L}$ of $10 \mathrm{X}$ second strand buffer (100 mM Tris- $\mathrm{HCl} \mathrm{pH} 7.5$; $50 \mathrm{mM} \mathrm{MgCl} 2 ; 75 \mathrm{mM}$ DTT), $2.5 \mu \mathrm{L}$ dNTPs $10 \mathrm{mM}, 1 \mu \mathrm{L} \mathrm{NAD}^{+} 15 \mathrm{mM}, 10 \mu \mathrm{L} \mathrm{KCl} 1 \mathrm{M}, 10 \mu \mathrm{L}$ (NH4) ${ }_{2} \mathrm{SO}_{4} 0.1 \mathrm{M}, 50 \mu \mathrm{L} \mathrm{H} \mathrm{H}_{2} \mathrm{O}, 25$ units E. coli DNA polymerase and 5 units E. coli DNA ligase (New England Biolabs). The mix was incubated at $14{ }^{\circ} \mathrm{C}$ for 12 hours and then at $70{ }^{\circ} \mathrm{C}$ for $10 \mathrm{~min}$. Two microliter of T4 DNA polymerase (3 units/ $\mu \mathrm{L}$; New England Biolabs) was added and the mix was incubated for $10 \mathrm{~min}$ at $37^{\circ} \mathrm{C}$. The cDNA was extracted with phenol-chloroform and precipitated with ethanol. The cDNA was ligated using the Rapid DNA ligation kit ${ }^{\circledR}$ (Roche) in the plasmid pUC19 (Yanisch-Perron et al., 1985) previously digested with $S m a I$ to generate blunt ends. Escherichia coli XL1-Blue competent cells were transformed with the ligation products and plated on Luria Bertani agar plates. A plasmid containing a $4.7 \mathrm{kbp}$ DNA fragment was identified and named pDWV11. Sequencing of the $4.7 \mathrm{kbp}$ cloned cDNA fragment was done by primer walking using the dideoxynucleotide sequencing method (Sanger et al., 1977).

\subsection{Sequence analysis}

Sequence alignments were performed using the Clustal W 1.8 program (Thompson et al., 1994). 
Table I. Detection of DWV in samples of adult bees, pupae and mites from four apiaries, during the year 2002. The geographical localization of each apiary in France is indicated below the apiary number.

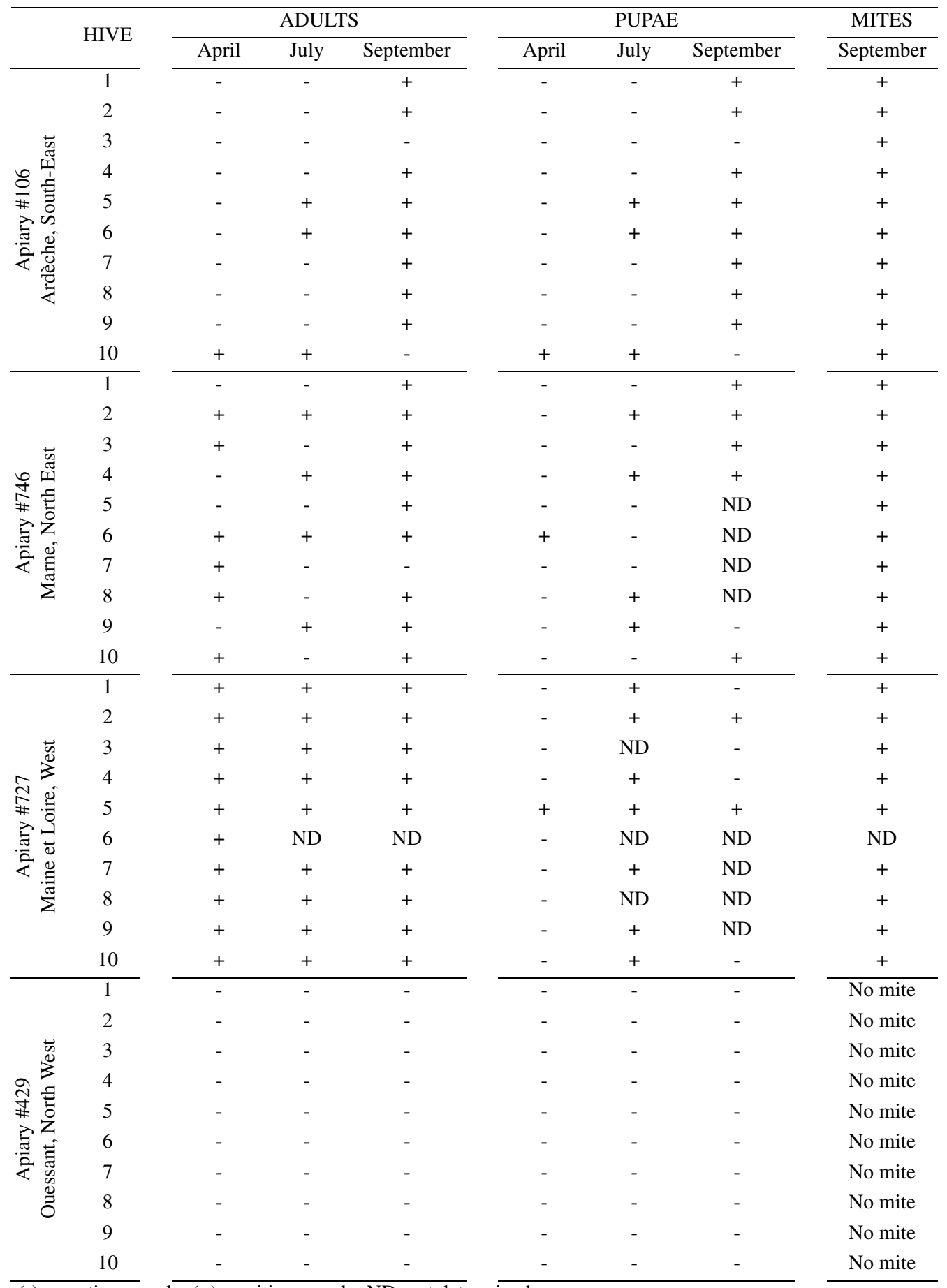

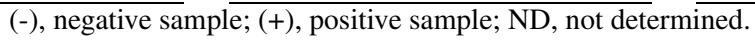


For sequence homology search, the database search program BLAST was used (Altschul et al., 1997; Marchler-Bauer et al., 2002).

\subsection{Nucleotide sequence accession number}

The DWV sequence described in this study was submitted to the GenBank database under accession number AY224602 (http://www.ncbi.nih.gov/Genbank/).

\subsection{Sample preparation for RT-PCR assays}

For individual analysis (Fig. 2), the samples were harvested from colony No. 7 of apiary \#746. The mites were directly collected from frozen infested adult bees. Each mite or bee was immediately homogenized in $400 \mu \mathrm{L}$ of a chaotropic salt buffer (RA1 solution of the RNA-II kit - MachereyNagel) in a $1.5 \mathrm{~mL}$ microtube using Piston pellet ${ }^{\circledR}$ (Eppendorf) as homogeniser. The total RNA was extracted following the RNA-II kit (MachereyNagel) protocol. After purification, total RNA was resuspended in $50 \mu \mathrm{L}$ of RNAse free water and quantified by spectrometry. Two microgram of total RNA was reverse transcribed at $25^{\circ} \mathrm{C}$ for $10 \mathrm{~min}$ utes and at $50{ }^{\circ} \mathrm{C}$ for one hour with the Thermoscript $^{\circledR}$ RT-PCR kit (Invitrogen) using random hexamers. Ultimately, the cDNA was diluted ten fold in water. For dilution limit assays, the cDNA was diluted to $1 / 10$ th in water before PCR analysis.

For large scale analysis (Tab. I), samples were crushed in a mortar in the presence of liquid nitrogen and homogenised in $20 \mathrm{~mL} \mathrm{TN}$ buffer $(10 \mathrm{mM}$ Tris; $0.4 \mathrm{M} \mathrm{NaCl}$; pH 7.5). After homogenisation, samples were centrifuged for $10 \mathrm{~min}$ at $5000 \mathrm{~g}$ for clarification. Fifty microliter of supernatant was used for total RNA extraction using RNA-II kit (Macherey-Nagel). The cDNA was synthesised as shown above.

\subsection{PCR assays}

The primers were deduced from the sequence of the $4.7 \mathrm{kbp}$ DWV cDNA fragment which corresponds to the putative RNA dependent RNA polymerase domain of the virus. The following primer sequences were designed using the Primer Express ${ }^{\circledR}$ software (Applied Biosystems):

DWV-T3-fwd: 5'-GTCGTGCAGCTCGATAGGAT-3'

DWV-T3-rev: 5'-TTTGCAAGATGCTGTATGTGG-3'

PCR assays were done in a $50 \mu \mathrm{l}$ final volume with $2 \mu \mathrm{L}$ of cDNA, $0.2 \mathrm{mM}$ dNTPs, $0.4 \mu \mathrm{M}$ of each primer, $5 \mu \mathrm{L}$ of $10 \mathrm{X}$ buffer (Q-Biogen) and 1 unit ot Taq polymerase (Q-Biogen). The PCR conditions were $94^{\circ} \mathrm{C}$ for $2 \mathrm{~min}, 35$ cycles $\left(94^{\circ} \mathrm{C}\right.$ for $30 \mathrm{~s}, 55^{\circ} \mathrm{C}$ for $30 \mathrm{~s}, 72^{\circ} \mathrm{C}$ for $1 \mathrm{~min}$ ), and $7 \mathrm{~min}$ at $72{ }^{\circ} \mathrm{C}$. The 395 nucleotide amplification product was analysed by agarose gel electrophoresis $(1.5 \%$ agarose), purified using the Nucleospin ${ }^{\circledR}$ purification kit (Macherey-Nagel) and sequenced (MWGBiotech) to ascertain the correctness of the DWV sequence.

\subsection{ELISA assays}

For serological assays, the mite and bee samples were analysed by indirect ELISA as described previously (Allen et al., 1986).

\section{RESULTS}

\subsection{Analysis of partial DWV genome}

Sequence analysis of the $4.7 \mathrm{kbp}$ viral insert of plasmid pDWV11 revealed a single major open reading frame of 1565 amino-acids.

At the nucleotidic level, a BLAST search (Altschul et al., 1997) showed no similarity with any viral sequences except with the two DWV sequences deposited in Genbank (Lanzi and Rossi, AJ489744, unpublished; de Miranda J., Cameron C.E. and Camazine S.M., AY292384.1, unpublished), which showed $98 \%$ identity on the whole pDWV11 sequence. The pDWV11 sequence also showed 85\% identity with the $V$. destructor virus 1 partial sequence (Ongus J.R., Peters D., Bengsch E., Vlak J.M. and Van Oers M.M., AY251269.1, unpublished).

At the amino-acid level, a BLAST analysis on the 1565 amino acids sequence detected similarity with the consensus domain of viral RNA dependent RNA polymerases $(38.1 \%$ matching in 196 residues) (Marchler-Bauer et al., 2002). This RNA polymerase domain of the DWV sequence displayed similarity with other insect viruses: sacbrood virus $(40 \%$ identity), acute bee paralysis virus (30\% identity), Kashmir bee virus (30\% identity), cricket paralysis virus (31\% identity), Drosophila C virus (32\% identity) (Fig. 1).

\subsection{PCR amplification}

To ascertain that the set of DWV primers designed to perform PCR assays were specific, 


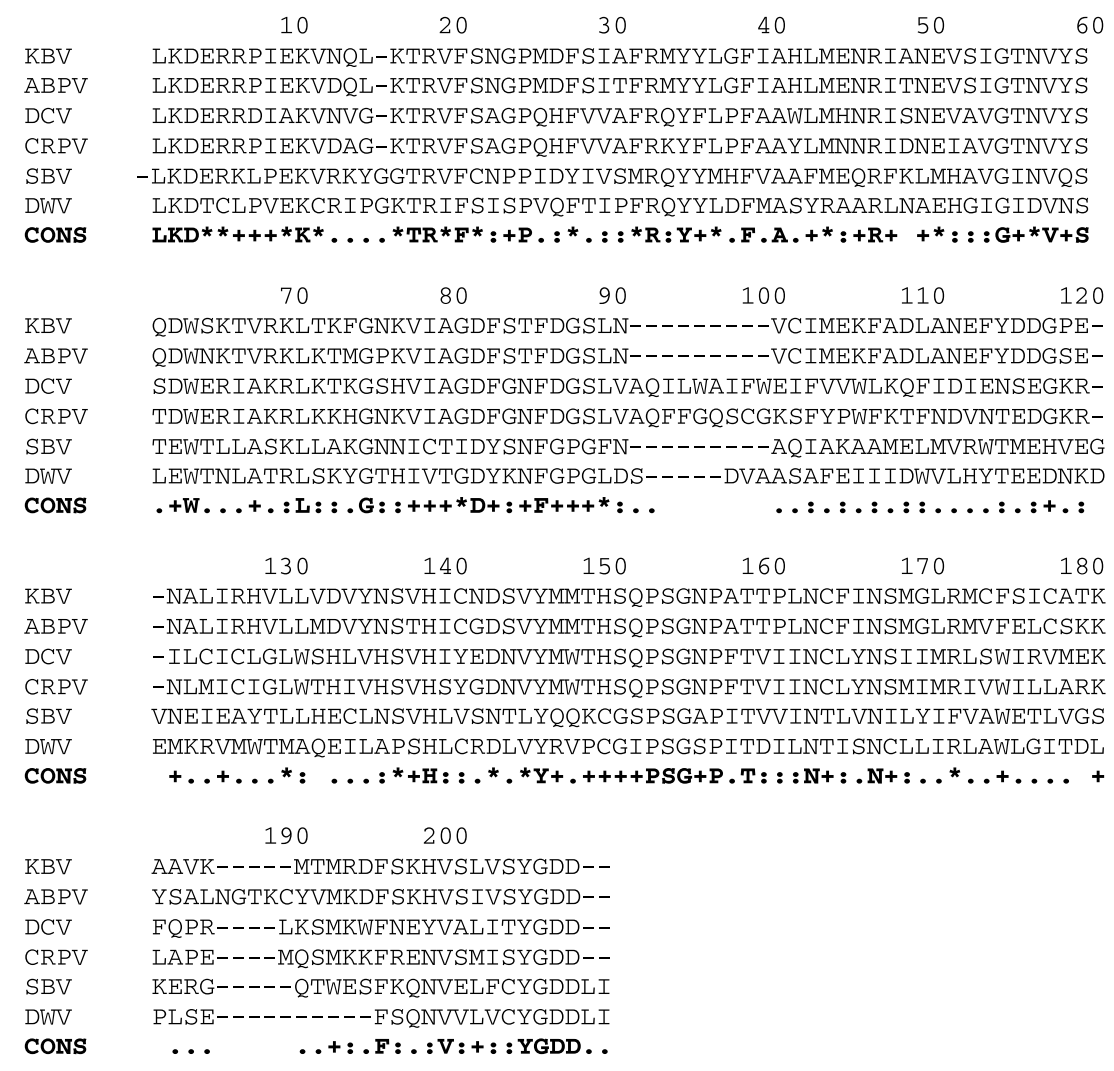

Figure 1. Alignment of KBV ABPV, DCV, CRPV, SBV and DWV amino acid sequences matching in the putative RNA polymerase RNA dependent domain. The Genbank references are: NP851403 (KBV), NP066241 (ABPV), NP044945 (DCV), NP647481 (CRPV), AAL79021 (SBV). The consensus sequence (Cons.) is shown below the sequences in bold characters.

several approaches were used. First, the sequences of the primers were matched against nucleotide databases and were found to be specific to the DWV sequence. Second, we tested the primers for their capacity to detect other bee viruses. No PCR products were produced by these primers from samples known to contain $\mathrm{KBV}, \mathrm{ABPV}, \mathrm{CBPV}, \mathrm{BQCV}$, or SBV. Finally, the 395 nucleotide $P C R$ products from five isolates collected from different places in France were sequenced and were found to be identical to the DWV sequence.

The assay was validated on a series of dilutions of the cDNAs synthesised from individual mite or bee samples collected from colony 7 in apiary \#746. (Fig. 2). Agarose gel electrophoresis of PCR products showed a 395 nucleotides DNA fragment in each sample analysed. In $V$. destructor, the signal was still visible in the $10^{7}$ dilution of the initial homogenate.

In a symptom-less bee (no deformed wings), the signal was detectable up to the dilution $10^{7}$, while in a bee showing deformed wings, the presence of DWV could be detected up to the dilution $10^{9}$. These assays were performed in triplicate on different mites and bees, producing consistent results throughout.

\subsection{Prevalence of DWV in adult bees and in pupae}

Four apiaries located in different regions of France were chosen for this survey. The results are summarized in Table I. Adult bees and pupae were collected in ten colonies of 


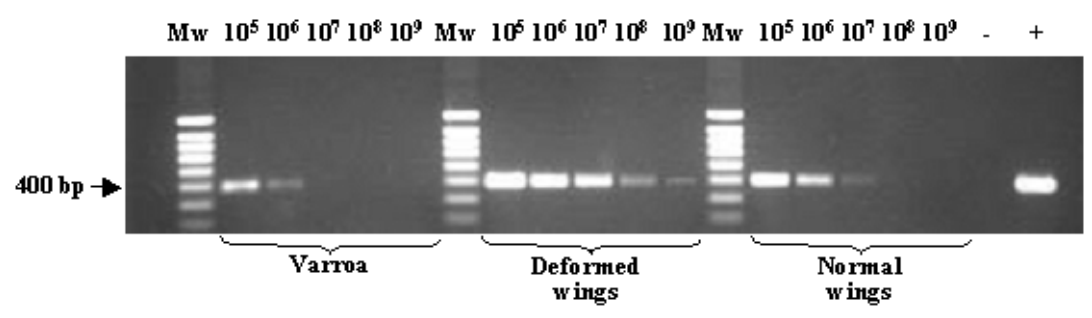

Figure 2. Agarose gel electrophoresis of PCR products. The DWV genome was amplified from a single varroa mites or a single bee. The cDNA corresponding to each sample was diluted several times before PCR assay. The dilution factor is indicated on the top of each lane. Mw: molecular weight (Smartladder SF, Eurogentec). +: positive control (plasmid pDWV11). -: negative control (water).

each apiary in April, July and September 2002. The prevalence of DWV in apiary \#727 (Maine et Loire, Centre of France) was 100\% in adult samples tested, regardless the period of the year. In apiaries \#106 (Ardèche, South East of France) and \#746 (Marne, North East of France), DWV frequencies in adults were 1/ 10 and 6/10 in April, 3/10 and 4/10 in July, and $8 / 10$ and $9 / 10$ in September, respectively. DWV frequencies in the brood samples collected in these apiaries in April were very low, with only one colony found positive in apiaries \#106, \#746 and \#727. In July, the number of colonies in which DWV was detected in the brood increased: 3/10 in apiary \#106, 4/10 in apiary \#746 and 7/7 in apiary \#727 and by September, most of the brood samples analysed were positive: $8 / 10$ in apiary \#106, 5/6 in apiary \#746, except for apiary \#727: 2/6. In contrast to the situation in the three other apiaries, no DWV was detected in apiary \#429. This apiary, located in Ouessant island (Britany, North West of France), is $V$. destructor-free (Louis Colleoc, personal communication).

\subsection{Prevalence of DWV in $V$. destructor}

$V$. destructor samples were collected in September 2002 from apiaries \#727, \#746 and \#106 after acaricide treatment and DWV was detected in all mite samples tested.

\section{DISCUSSION}

The RT-PCR technology was successfully used to diagnose deformed wing virus in $A$. mellifera and $V$. destructor populations.
The virus sample used to clone the DWV genome was isolated from a $V$. destructor homogenate identified as containing DWV in an ELISA assay. Since multiple infections are common in honey bees (Anderson, 1995), we carefully verified the absence of other bee viruses in this sample both by ELISA and PCR tests. Starting from a purified virus suspension, we have cloned a $4.7 \mathrm{Kbp}$ cDNA fragment corresponding to the 3'-end of the viral genome. The partial sequencing of this fragment revealed a single open reading frame of 1565 amino acids showing conserved residues typical of the viral RNA-dependent RNA polymerase (Marchler-Bauer et al., 2002). These data show that DWV belongs to the Iflaviruses (Mayo et al., 2003) and is distantly related to sacbrood virus $(40 \%$ amino-acids aligned on 196 amino acids). However, the lack of significant identity between the $4700 \mathrm{bp}$ sequence of DWV and the sequences in the databases clearly indicates that DWV is definitely different from the other bee viruses already sequenced.

The DWV detection assay by PCR using the primers that we designed was validated both by demonstrating its high specificity (no amplification of KBV, ABPV, CBPV, BQCV or SBV), and by analysing single mites or single bees. DWV was detected at the $10^{7}$ dilution of a bee sample showing no deformed wing symptom and up to dilution $10^{9}$ for a deformed wing bee sample. These results show that the bees with deformed wings contained at least 10 to 100 times more DWV particles than the symptom-less ones. It thus appears that bees can have high DWV titres without apparent symptoms. However, above a given threshold, one can hypothesize that 
DWV replication would induce the wing deformities.

The prevalence of the DWV was investigated in adult bees, bee pupae and mites, in 4 apiaries located in different regions of France. Although limited to a few apiaries, our data suggested that deformed wing virus in bee and mite populations is probably prevalent in most French apiaries. With the exception of apiary \#429 (Ouessant Island) where no DWV was detected in any of the 10 colonies tested, the virus was detected in 29 out of 30 colonies from the other 3 apiaries during the course of the 2002 year. The exception was colony 3 of apiary \#106. Keeping in mind that DWV might be able to persist at low levels in adult bees as reported for other bee viruses (Dall, 1985; Anderson and Gibbs, 1988), the frequency values recorded in this study could be higher.

Virus prevalence from bee pupae was generally lower than in adult bees. This was particularly evident in the pupae collected in April 2002, since only 3 pupae samples out of the 30 analysed proved positive. However, by the end of summer, these values raised significantly (e.g. 8 colonies out of 10 analysed in apiary \#106 were found positive).

The increased prevalence of DWV during the course of the year correlates well with increasing mite infestation in apiaries. Mite populations increase from spring to late summer, when control treatments are administered by beekeepers. A link between $V$. destructor infestation and DWV prevalence in adult bees and brood is suggested by results in apiary \#727 where pupae were severely infested in July and September.

Interestingly, we were not able to detect DWV in the varroa-free apiary \#429, located in the Ouessant Island. Since the early eighties, no bee colony has been introduced from the continent to this island (Louis Colleoc, personal communication). Only young larvae carefully checked for the absence of mites have been introduced on the island for queen production. Since there is a high probability that these larvae come from DWV positive continental colonies, our results suggest that DWV might not be vertically transmitted.

Taken together, our results confirm the close relationship between $V$. destructor infes- tation and DWV prevalence in honey bee colonies and are in good agreement with the role of this mite in transmitting the virus (BowenWalker et al., 1999).

\section{ACKNOWLEDGEMENTS}

Diana Tentcheva and Laurent Gauthier contributed equally to this work. We thank Dr F.X. Jousset for her technical help, and French beekeepers for sample collection. This work was supported by the EEC and the French Ministère de l'Agriculture et de la Pêche (Règlement CE No. 1221/97, convention No. 2207).

Rothamsted Research receives grant-aided support from the Biotechnology and Biological Sciences Research Council of the UK.

Résumé - Détection par PCR du virus des ailes déformées (DWV) chez Apis mellifera et Varroa destructor. Un grand nombre de virus infectent l'abeille domestique Apis mellifera $\mathrm{L}$. A ce jour, les génomes de six d'entre eux ont été totalement ou en partie séquencés : il s'agit des virus ABPV (virus de la paralysie aiguë), KBV (virus du Cachemire), BQCV (virus des cellules noires de reine), SBV (virus du couvain sacciforme), CBPV (virus de la paralysie chronique ou maladie noire), et DWV (virus des ailes déformées). Le virus des ailes déformées est suspecté de provoquer l'apparition de déformations alaires au cours de la nymphose de l'abeille. Ces symptômes sont souvent visibles sur quelques abeilles au sein de la colonie, et sont associés à de fortes infestations par Varroa destructor. La présence d'abeilles avec ailes déformées est relevée plus fréquemment en automne par les apiculteurs.

Pour tenter d'établir un lien entre le virus DWV et la présence de symptômes d'ailes déformées, nous avons développé une méthode d'identification du virus des ailes déformées par la technique d'amplification génique (PCR). L'utilisation de cette technique de diagnostic très performante nécessite la connaissance préalable du génome de l'organisme cible. Le séquençage partiel du génome du virus DWV a été réalisé après purification du virus à partir d'un broyat de varroas. L'ARN viral a été transcrit en $\mathrm{ADN}$ et un fragment génomique de 4700 nucléotides a été cloné dans un plasmide. Le séquençage de ce fragment a révélé un cadre ouvert de lecture unique de 1565 acides aminés. La comparaison de cette séquence avec les banques de données a permis de déceler une forte parentée avec la séquence consensus des ARN polymérases ARN dépendantes virales, particulièrement celle du virus du couvain sacciforme (Fig. 1). Un couple d'amorces a été choisi à partir de la séquence du DWV pour amplifier un fragment de 395 nucléotides. La spécificité des amorces a été vérifiée par comparaison 
avec les banques de données. D'autre part, nous avons démontré l'absence d'amplification d'autres génomes viraux par ce même couple d'amorces.

Le test a été validé à partir d'échantillons de $V$. destructor ou d'abeille analysés individuellement (Fig. 2). Il montre que les abeilles peuvent tolérer de fortes concentrations de virus DWV sans manifester de symptômes apparents. Nous avons relevé néanmoins une concentration plus forte de DWV chez les individus présentant des ailes déformées. Chez V. destructor, le virus est aussi présent en très fortes concentrations, ce qui laisse supposer que l'acarien puisse contribuer à propager le virus DWV dans et entre les différentes colonies d'abeilles. Cette hypothèse est confortée par l'analyse d'échantillons prélevés au cours d'une année dans quatre ruchers en France (Tab. I). Les résultats montrent une augmentation très nette en automne des fréquences de détection de DWV dans les abeilles adultes et dans le couvain. Le virus DWV a été détecté dans tous les échantillons d'acariens prélevés en septembre dans ces mêmes ruchers. Il semble donc que le virus DWV soit peu pathogène pour l'abeille domestique et pour $V$. destructor, en dépit des fortes concentrations relevées dans les échantillons ainsi que des fortes fréquences avec lequel ce virus est distribué dans les colonies.

\section{virus d'abeille / diagnostic / Varroa destructor /} virus des ailes déformées (DWV)

\footnotetext{
Zusammenfassung - Polymerase Kettenreaktions-Diagnose des Flügeldeformations-Virus (DWV) in Apis mellifera und Varroa destructor. Es gibt eine große Anzahl Vireninfektionen bei Honigbienen (Apis mellifera L.). Bis heute sind die Genome von sechs dieser Viren ganz oder teilweise sequenziert. Es handelt sich hierbei um das ABVVirus (akutes Brut-Paralyse-Virus), das KBV (Kaschmir-Virus), das BQCV (schwarze Königinnenzellen-Virus), das SBV (Sackbrut-Virus), das CBPV (chronisches Brutparalyse- oder Schwarzsucht-Virus) und das DWV (FlügeldeformationsVirus / veränderte Flügel-Virus). Das DWV-Virus wird verdächtigt, Flügeldeformation während der Pupalphase der Biene zu verursachen. Die Symptome werden vor allem bei Bienen beobachtet, die sich im Zentrum eines Volks aufhalten, und sie sind meist mit einem starken Befall von Varroa destructor verbunden. Bienen mit solchen Flügeldeformationen werden vom Imker meist im Herbst wahrgenommen.

Um die Verbindung zwischen dem DWV-Virus und dem Auftreten der Flügeldeformations-Symptome ursächlich festmachen zu können, haben wir uns einer Methode der Virusidentifizierung mittels PCR (Polymerasekettenreaktion) bedient. Die Anwendung einer solchen Diagnosemethode bedarf einiger Vorkenntnisse über das Genom des betreffenden Organismus. Für die Teilsequenzierung des DWV-Genoms wurde das Virus aus einem Varroa-
}

milben-Extrakt aufgereinigt. Die virale RNA wurde in DNA revers transkribiert und ein Genomfragment von 4700 Nucleotiden wurde schließlich in einem Plasmid kloniert. Die Sequenzierung des Fragments resultierte in einem einzigen offenen Leseraster von 1565 Aminosäuren. Der Sequenzvergleich mit entsprechenden Datenbanken ergab eine hohe Ähnlichkeit mit einer KonsensusSequenz für virale RNA-abhängige RNA-Polymerasen, insbesondere mit der des Sackbrutvirus (Abb. 1 und Abb. 2). Basierend auf dieser Sequenz entwickelten wir ein Set an Primern, mittels deren ein Fragment von 395 Nucleotiden amplifiziert werden konnte. Die Spezifität der Primer wurde durch Sequenzvergleich gegen die entsprechenden Datenbanken getestet. Als Negativkontrolle testeten wir die Primer an anderen viralen Genomen, die alle keine Amplifikationsprodukte lieferten.

Zur Validierung wurden Tests mit Proben von einzelnen Varroamilben oder Bienen durchgeführt (Abb. 2). Dies zeigte, dass Bienen eine hohe Konzentration an DWV-Virus tolerieren können, ohne dass sie Symptome zeigen. Bienen mit Flügeldeformation wiesen nichtsdestotrotz eine noch höhere Konzentration an DWV auf. Auch bei Varroamilben waren sehr hohe Konzentrationen des Virus zu finden, was darauf schließen lässt, dass die Milbe bei der Virusübertragung innerhalb und zwischen Bienenvölkern eine wichtige Rolle spielen kann. Diese Hypothese bestätigte sich auch in den Analysen von Proben, die im Verlauf eines Jahres aus verschiedenen Völkern entnommen wurden (Tab. I). Diese Resultate zeigten im Herbst einen klaren Anstieg in der Frequenz, mit der DWV in adulten Bienen und im Stock gefunden werden konnte. Das DWV-Virus wurde auch in allen Varroa-Proben gefunden, die im September aus diesen Völkern gezogen wurden. Die weist darauf hin, dass das DWV-Virus für die Honigbiene und Varroamilbe nur wenig pathogen ist, trotz der hohen Konzentrationen, die wir in den Proben fanden und der hohen Frequenz, mit der wir das Virus in den Völkern verbreitet ist.

\section{Varroa destructor / Flügeldeformations-Virus (DWV) / Diagnose / Bienenvirus}

\section{REFERENCES}

Allen M.F., Ball B.V., White R.F., Antoniw J.F. (1986) The detection of acute paralysis virus in Varroa jacobsoni by the use of a simple indirect ELISA, J. Apic. Res. 25, 100-105.

Altschul S.F., Madden T.L., Schäffer A.A., Zhang J., Zhang Z., Miller W., Lipman D.J. (1997) Gapped BLAST and PSI-BLAST: a new generation of protein database search programs, Nucl. Acid. Res. 25, 3389-3402.

Anderson D.L., Gibbs A.J. (1988) Inapparent virus infections and their interactions in pupae of the 
honey bee (Apis mellifera L.) in Australia, J. Gen. Virol. 69, 1617-1625.

Anderson D.L. (1995) Viruses of Apis cerana and Apis mellifera, in: The Asiatic Hive Bee: Apiculture, Biology, and Role in Sustainable Development in Tropical and Subtropical Asia, Enviroquest, Ltd., Cambridge, Ontario, Canada, pp. 161-170.

Anderson D.L., Trueman J.W.H. (2000) Varroa jacobsoni (Acari: Varroidae) is more than one species, Exp. Appl. Acarol. 24, 165-189.

Bailey L., Ball B.V. (1991) Honey Bee pathology, 2nd ed., Academic Press, London.

Ball B.V. (1989) Varroa jacobsoni as a virus vector, Present status of varroatosis in Europe and progress in varroa mite control, in: Cavalloro R. (Ed.), Proc. meeting of EEC expert's group, Udine, Italy, 28-30 November 1988, pp. 241244. Office for Official Publications of the European Communities, Luxembourg.

Benjeddou M., Leat N., Allsopp M., Davison S. (2001) Detection of acute bee paralysis virus and black queen cell virus from honeybees by reverse transcriptase PCR, Appl. Environ. Microbiol. 67, 2384-2387.

Bowen-Walker P.L., Martin S.J., Gunn A. (1999) The transmission of Deformed Wing Virus between honeybees (Apis mellifera L.) by the ectoparasitic mite Varroa jacobsoni Oud, J. Invertebr. Pathol. 73, 101-106.

Dall D.J. (1985) Inapparent infection of honey bee pupae by Kashmir and Sacbrood bee viruses in Australia, Ann. Appl. Biol. 106, 461-468.

Grabensteiner E., Ritter W., Carter M.J., Davison S., Pechhacker H., Kolodziejek J., Boecking O.,
Derakhshifar I., Moosbeckhofer R., Licek E., Nowotny N. (2001) Sacbrood virus of the honeybee (Apis mellifera): rapid identification and phylogenetic analysis using reverse transcription-PCR, Clin. Diagn. Lab. Immunol. 8, 93-104.

Marchler-Bauer A., Panchenko A.R., Shoemaker B.A., Thiessen P.A., Geer L.Y., Bryant S.H (2002) CDD: a database of conserved domain alignments with links to domain three-dimensional structure, Nucl. Acid. Res. 30, 281-283.

Mayo M.A., Fauquet C.M., Maniloff J. (2003) Taxonomic proposals on the Web: new ICTV consultative procedures, Arch. Virol. 148, 609611.

Ribière M., Triboulot C., Mathieu L., Aurières C., Faucon J.P., Pépin M. (2002) Molecular diagnostic of chronic bee paralysis virus infection, Apidologie 33, 339-351.

Sanger F., Nickler S., Coulson A.R. (1977) DNA sequencing with chain terminating inhibitors, Proc. Natl. Acad. Sci. (USA) 74, 5463-5467.

Stoltz D., Shen X.R., Boggis C., Sisson G. (1995) Molecular Diagnostic of Kashmir bee virus infection, J. Apic. Res. 34, 153-165.

Thompson J.D., Higgins D.G., Gibson T.J. (1994) CLUSTAL W: improving the sensitivity of progressive multiple sequence alignment through sequence weighting, position specific gap penalties and weight matrix choice, Nucl. Acid. Res. 22, 4673-4680.

Yanisch-Perron C., Vieira J., Messing J. (1985) Improved M13 phage cloning vectors and host strains: nucleotide sequences of the M13mp18 and pUC19 vectors, Gene. 33, 103-119. 